Old Dominion University

ODU Digital Commons

Dental Hygiene Faculty Publications

Dental Hygiene

2016

\title{
Assessment of Mass Fatality Preparedness and Response Content in Dental Hygiene Education
}

Ann M. Bruhn

Old Dominion University

Tara L. Newcomb

Manasi Sheth-Chandra

Follow this and additional works at: https://digitalcommons.odu.edu/dentalhygiene_fac_pubs

Part of the Dental Hygiene Commons

\section{Repository Citation}

Bruhn, Ann M.; Newcomb, Tara L.; and Sheth-Chandra, Manasi, "Assessment of Mass Fatality Preparedness and Response Content in Dental Hygiene Education" (2016). Dental Hygiene Faculty Publications. 32.

https://digitalcommons.odu.edu/dentalhygiene_fac_pubs/32

\section{Original Publication Citation}

Bruhn, A. M., Newcomb, T. L., \& Sheth-Chandra, M. (2016). Assessment of mass fatality preparedness and response content in dental hygiene education. Journal of Dental Education, 80(5), 605-611.

This Article is brought to you for free and open access by the Dental Hygiene at ODU Digital Commons. It has been accepted for inclusion in Dental Hygiene Faculty Publications by an authorized administrator of ODU Digital Commons. For more information, please contact digitalcommons@odu.edu. 


\title{
Assessment of Mass Fatality Preparedness and Response Content in Dental Hygiene Education
}

\begin{abstract}
Ann M. Bruhn, MS; Tara L. Newcomb, MS; Manasi Sheth-Chandra, PhD
Abstract: When mass fatality incidents (MFIs) occur, they can quickly overwhelm local, state, and government agencies, resources, and personnel. It is important to have a rapid and effective response with skilled, multidisciplinary victim identification teams since specific skill sets are necessary to participate in mass fatality preparedness and response. The aims of this study were to determine the extent of formal education related to mass fatality preparedness and response training in U.S. dental hygiene programs and to assess program directors' perceptions of the need for such training. A 23 -item cross-sectional survey was emailed to 319 U.S. dental hygiene programs in 2015. Survey questions addressed if the program offered mass fatality preparedness and response training to its students and how much training was given, as well as collecting respondents' demographics and opinions regarding education and training. An overall response rate of $36 \%$ was obtained, with 111 program chairs completing the survey. The results showed that only a small percentage of responding programs incorporated coursework related to mass fatality and preparedness in their curricula. Of the responding programs, $84 \%$ had no formal instruction on the role of a dental hygienist in MFIs; however, 53 of 69 program directors agreed or strongly agreed that the role of dental hygienists in MFIs should be covered in dental hygiene curricula. The top three barriers to incorporating such training reported by respondents were time requirements, lack of faculty expertise, and lack of equipment. Future research is needed to establish standardized competencies for mass fatality preparedness and response in dental hygiene education.
\end{abstract}

Prof. Bruhn is Assistant Professor, School of Dental Hygiene, Old Dominion University; Prof. Newcomb is Assistant Professor, School of Dental Hygiene, Old Dominion University; and Dr. Sheth-Chandra is with the Center for Global Health, School of Community and Environmental Health, Old Dominion University. Direct correspondence to Prof. Ann M. Bruhn, School of Dental Hygiene, Old Dominion University, 4608 Hampton Blvd., Health Sciences Building, Room 2001, Norfolk, VA 23529; 757-683-3851; abruhn@odu.edu.

Keywords: dental hygiene, dental hygiene education, allied dental education, mass fatality incident, rapid response, disaster training

Submitted for publication 10/2/15; accepted 11/19/15

$\mathrm{D}$ isasters have the potential for mass casualties or mass fatality incidents (MFIs). ${ }^{1-3}$ MFIs are defined as emergency situations in which the number of deaths caused by either manmade or natural disasters overwhelm community resources. ${ }^{1}$ The Annual Disaster Statistical Review reported that 324 natural disasters resulted in approximately 7,823 deaths and $\$ 99.2$ billion worth of damages worldwide in 2014. ${ }^{1}$ China, the United States, India, Japan, and the Philippines were the top five countries affected and accounted for $31.1 \%$ of total occurrence. Consequently, those countries experienced the highest number of disaster events on average, with the U.S. having 20 natural disasters in 2014. The Swiss Re Natural Catastrophes and Man-Made Disasters Report for 2014 estimated that global financial losses from natural and man-made catastrophes combined cost countries $\$ 35$ billion in 2014 , with approximately 27,000 and 12,700 deaths in 2013 and 2014, respectively. ${ }^{4}$ It has been estimated that natural disasters are more damaging and have a higher mortality rate than man-made disasters because natural disasters are unmanageable while man-made disasters are preventable. ${ }^{5}$

Disasters and coinciding MFIs are hard to prepare for because each event has its own set of challenges for state and local governing bodies, law enforcement, health care providers, and emergency management personnel, including the potential for serious impact on the community from large-scale and widespread devastation. MFIs are pivotal events that require emergency managers, public health professionals, and government officials to anticipate and prepare for effective efforts to introduce in response. In addition, communities must continually develop improved capabilities for future incidents. Each incident requires multi- and interdisciplinary teams of individuals, both professional and volunteer. ${ }^{5-8}$

Today, the Department of Homeland Security's Target Capabilities List provides national preparedness guidelines that identify use of dental teams and response missions for victim identification under the Department of Health and Human Services. ${ }^{9}$ Dental teams consist of forensic odontologists, dentists, 
dental hygienists, and dental assistants. Critical tasks outlined in the Target Capabilities List for dental teams include regular training and mock exercises, identifying anatomical dental remains, and making individual victim identifications. Nationally, dental professionals are recognized as important members of the health care community who can respond and assist during MFIs to meet local public health needs. ${ }^{7}$

Forensic odontologists have outlined and advocated for the role of dental hygienists in MFI victim identification efforts. ${ }^{6,10-12}$ The earliest account of specific roles dental hygienists performed during an MFI is Rawson et al.'s report of the 1980 MGM Grand Hotel and Casino fire in Las Vegas, during which 82 people were killed. ${ }^{11}$ During that event, four dental hygienists worked with three dentists in obtaining postmortem records and imaging dental radiographs of the fire victims. In Rawson et al.'s account, the dental hygienists were a "valuable resource" because of their knowledge in radiographic technique, dental charting, and management skills. More recently, Zohn et al. reported that "approximately 350 US dentists and dental auxiliary" contributed to forensic identification needs after the World Trade Center terrorist attacks. ${ }^{13}$ This article specifically recommended that dental hygienists be part of dental record identification teams in the future. Other forensic odontology researchers have acknowledged that formal education in dental hygiene serves as a good foundation and that additional courses, training, and experience in MFIs can increase skills when needed for disaster efforts. ${ }^{10}$

While research articles have outlined roles, skills, and utilization of dental hygienists for MFIs, education-based research in this area is scarce..$^{6,10-12}$ Even in dental education, there are no standardized competencies or methods of instruction for delivering MFI content although several authors have advocated the need for such training in dental and dental hygiene education. ${ }^{4,5,7,12,14,15}$ In addition, Brannon and Connick identified the need for increased disaster education and training and specifically recommended taking a multidisciplinary approach in disaster preparedness and response courses for both dental and dental hygiene students. ${ }^{6}$ However, there has been no previous research on educators' perceptions of and willingness to add MFI content to dental hygiene curricula.

Deployment to help with recovery efforts requires all dental professionals to have individual and collective training designed to decrease the occupational and environmental threats. ${ }^{16}$ The use of inexperienced volunteers can be problematic for determining exact skill and experience levels. ${ }^{10,13}$ Newcomb et al. identified the need for dental hygiene competencies and standardization of educational content in order to prepare volunteers during and after MFIs ${ }^{12}$ while Coleman explained the need for integrating disaster preparedness into all health professions education..$^{5}$ In light of these calls, the aims of our study were to determine the extent of formal education related to mass fatality preparedness and response training in U.S. dental hygiene programs and to assess program directors' perceptions of the need for such training.

\section{Materials and Methods}

This study received exempt status by the Old Dominion University College of Health Science Institutional Review Board. The 23-item cross-sectional survey, designed by the authors, was reviewed and pilot tested for content validity by an expert panel of faculty members. This panel included several faculty members with Medical Reserve Corps training specific to disaster preparedness, a department chair, and two faculty members with previous real world dental victim identification experience. Minor clarifications were made to the survey in response to the pilot test.

In addition to collecting demographic information, survey items asked about types of MFI-related education currently offered in the dental hygiene program and the program directors' perception of the need for MFI education in dental hygiene curricula. Other questions asked whether an MFI (natural or man-made) had recently occurred in the respondent's state of residence, if the respondent had participated in an actual MFI, and if the respondent was a member of any disaster preparedness and response groups. Respondents were also asked to indicate their perceived importance of a list of potential curriculum topics and to identify perceived barriers to adding MFI-related training to their curricula. Response formats on the survey were select all that apply, rating scale, and yes/no questions. Comment boxes were used to solicit open responses where applicable.

A list of dental hygiene programs was obtained during the 2014-15 academic year from the American Dental Hygienists' Association (ADHA) Education and Careers webpage, and the program directors $(\mathrm{N}=319)$ were sent an electronic announcement of the study. A Qualtrics system was used to upload and send the survey and cover letter. Program directors had two months to complete the survey. Two 
follow-up emails were sent to all directors two weeks after the initial electronic invitation. Responses were coded and entered into a database for statistical analysis. Data analysis included descriptive statistics, comparisons, percentages, and cross-tabulations for associations between the variables using Fisher's exact test.

\section{Results}

Of the 319 U.S. dental hygiene program directors invited to participate in the study, 11 emails were returned for a sample of 308. A total of 111 directors completed the survey, for a response rate of $36 \%$. Most of the program directors had a master's degree $(77 \%)$ and worked full-time (98\%); 79\% were employed in a dental hygiene program that offered an associate degree. Their general teaching experience ranged from one to $40+$ years. Nearly all $(95 \%)$ indicated their program was not affiliated with a dental school. Participants were from all regions of the United States; however, the largest percentages were from the South and the West (Table 1).

The respondents perceived that flooding (69\%), tornados $(63 \%)$, major transportation accidents (58\%), and terrorism (53\%) caused susceptibility to an MFI. Of the respondents, $75 \%$ reported that a natural or man-made disaster involving mass fatalities had not occurred in their state in the past five to ten years, and $90 \%$ had never participated in a response to an MFI. The majority (89\%) were not a member of any disaster preparedness and response groups such as the American Red Cross or Disaster Mortuary Operational Response Teams.

Most respondents (73\%) reported believing that dental hygienists have a moral obligation to help with disaster preparedness and response dur- ing MFIs, and $89 \%$ said they felt dental hygienists could play a vital role in response efforts. However, the majority $(84 \%)$ reported their program had no training on the role of the dental hygienist for MFIs; $92 \%$ said the program had no current mass fatality preparedness course offerings. Respondents from the $16 \%$ of programs that did have MFI training reported that radiology, anatomy, medical emergencies, theory, and community courses were included as formal instruction. Among the responding program directors, $72 \%$ were interested in MFI curriculum development, and 54\% reported believing the role of a dental hygienist for MFIs should be covered in the curriculum. Respondents reported that the most important topics were PPE suit-ups in mortuary settings $(57 \%)$, radiation safety and technique for postmortem dental radiographs (56\%), working in a multidisciplinary setting, and volunteering for MFIs (60\%). The respondents' perceived barriers to including mass fatality preparedness and response in the dental hygiene curriculum are shown in Table 2.

We also performed cross tabulations between the variables of formal MFI-related instruction in a dental hygiene program and perceived importance of formal education on the role of dental hygienists in MFIs (Table 3). The Fisher's exact test (Test Statistic $=0.011, \mathrm{p}$-value 0.015$)$ indicated the two variables were associated: that is, having a dental hygiene program that offered formal instruction on mass fatality preparedness and response training was significantly associated with the program director's perceived importance of including the role of dental hygienists in MFIs.

Of the programs offering formal MFI-related instruction, 13 had an affiliation or membership in the following organizations: American Board of Forensic Odontology, American Red Cross, Disaster Mortuary Operational Response Teams, Emergency

Table 1. Region of study participants by number and percentage of total respondents $(\mathrm{N}=111)$

\begin{tabular}{|c|c|}
\hline Region & Number $(\%)$ \\
\hline $\begin{array}{l}\text { Northeast (New England, Connecticut, Delaware, Maine, Massachusetts, New Hampshire, Rhode Island, } \\
\text { Vermont) }\end{array}$ & $6(5 \%)$ \\
\hline Mid-Atlantic (New Jersey, New York, Pennsylvania) & $11(10 \%)$ \\
\hline $\begin{array}{l}\text { Midwest (Illinois, Indiana, Michigan, Ohio, Wisconsin, lowa, Kansas, Minnesota, Missouri, Nebraska, } \\
\text { North Dakota, South Dakota) }\end{array}$ & $29(26 \%)$ \\
\hline $\begin{array}{l}\text { South (Florida, Georgia, Maryland, North Carolina, South Carolina, Virginia, Washington, DC, West Virginia, } \\
\text { Alabama, Kentucky, Mississippi, Tennessee, Arkansas, Louisiana, Oklahoma, Texas) }\end{array}$ & $35(32 \%)$ \\
\hline $\begin{array}{l}\text { West (Arizona, Colorado, Idaho, Montana, Nevada, New Mexico, Utah, Wyoming, Alaska, California, } \\
\text { Hawaii, Oregon, Washington) }\end{array}$ & $30(27 \%)$ \\
\hline
\end{tabular}


System for Advance Registration of Volunteer Health Professionals, and Medical Reserve Corps. We also performed cross tabulations for the variables of presence of affiliation/membership in disaster preparedness and response groups, occurrence of natural disaster or man-made disaster with mass fatalities, and participation in response to an MFI (Table 4). The Fisher's exact test (Test Statistic $=0.001$, $\mathrm{p}$-value 0.001 ) indicated that having an affiliation/membership in disaster preparedness and response groups

Table 2. Perceived barriers to mass fatality preparedness and response training, by number and percentage of total respondents $(\mathrm{N}=111)$

\begin{tabular}{lc} 
Barrier & Number $(\%)$ \\
\hline Time requirements & $99(89 \%)$ \\
Lack of faculty expertise & $87(78 \%)$ \\
Lack of equipment & $82(74 \%)$ \\
Lack of faculty interest & $26(23 \%)$ \\
Liability concerns & $21(19 \%)$ \\
Too gruesome & $7(6 \%)$ \\
Too depressing/sad & $6(5 \%)$ \\
I do not see any barriers & $6(5 \%)$ \\
Other & $14(13 \%)$
\end{tabular}

Note: Respondents could choose all that applied. was significantly associated with offering formal MFI-related instruction. The Fisher's exact test (Test Statistic $=0.029, \mathrm{p}$-value 0.068 ) indicated that occurrence of natural or man-made disasters with MFIs in the respondents' state and formal MFI-related instruction were not associated. However, the variable of program directors with a history of participation in MFIs was significantly associated with having formal MFI-related instruction in the curriculum (Test Statistic $=0.001$, p-value 0.001).

Finally, cross tabulations between the variables of program directors' belief in covering the role of dental hygienists in MFIs in the curriculum and the variety of formal instruction that could be included in coursework were analyzed (Table 5). Respondents suggested instruction topics including personal protective equipment, suit up and infection control in mortuary settings, oral photography, postmortem radiation safety and technique, assisting with jaw resections, documenting postmortem findings in victim identification software systems, working in multidisciplinary settings, and family assistance. The test statistics indicated a significant association between the perceived importance of the curriculum topics and inclusion of dental hygienists for MFI response in the curriculum.

Table 3. Cross tabulation of dental hygiene programs offering formal mass fatality incident (MFI) instruction with program directors' belief that role of dental hygienists in MFIs should be covered in dental hygiene curricula

\begin{tabular}{llccc} 
Item & Responses & $\begin{array}{c}\text { Has Formal } \\
\text { Instruction }\end{array}$ & $\begin{array}{c}\text { No Formal } \\
\text { Instruction }\end{array}$ & Total \\
\hline Role of dental hygienists in MFIs should be & Agree or strongly agree & 15 & 38 & 53 \\
covered in dental hygiene curricula & Disagree or strongly disagree & 0 & 16 & 16 \\
& Total & 15 & 54 & 69
\end{tabular}

Table 4. Cross tabulation of dental hygiene programs that offer formal instruction in mass fatality incidents (MFIs) and catastrophe participation variables

\begin{tabular}{|c|c|c|c|c|c|c|}
\hline \multirow[b]{2}{*}{ Catastrophe Participation } & & \multicolumn{3}{|c|}{$\begin{array}{l}\text { Presence of Formal } \\
\text { MFI Instruction }\end{array}$} & \multicolumn{2}{|c|}{ Tests of Association } \\
\hline & & Yes & No & Total & $\begin{array}{l}\text { Test-Statistic } \\
\text { Value }\end{array}$ & p-value \\
\hline $\begin{array}{l}\text { Affiliation/membership in disaster preparedness } \\
\text { and response groups }\end{array}$ & $\begin{array}{l}\text { Yes } \\
\text { No }\end{array}$ & $\begin{array}{c}13 \\
9\end{array}$ & $\begin{array}{c}6 \\
88\end{array}$ & $\begin{array}{l}12 \\
97\end{array}$ & 0.001 & $<0.001$ \\
\hline $\begin{array}{l}\text { Occurrence of natural disaster or manmade } \\
\text { disaster with MFIs }\end{array}$ & $\begin{array}{l}\text { Yes } \\
\text { No }\end{array}$ & $\begin{array}{l}8 \\
9\end{array}$ & $\begin{array}{l}21 \\
72\end{array}$ & $\begin{array}{l}29 \\
81\end{array}$ & 0.029 & 0.068 \\
\hline $\begin{array}{l}\text { Participation in response to an MFI (e.g., Hurricane } \\
\text { Katrina, } 9 / 11 \text {, airplane crash) }\end{array}$ & $\begin{array}{l}\text { Yes } \\
\text { No }\end{array}$ & $\begin{array}{l}9 \\
8\end{array}$ & $\begin{array}{c}2 \\
91\end{array}$ & $\begin{array}{l}11 \\
99\end{array}$ & 0.001 & $<0.001$ \\
\hline
\end{tabular}

Note: For tests of association, since the expected cell counts were less than 5, Fisher's exact test was used to compute the Test Statistic (Probability) and its corresponding p-value. Disaster preparedness and response groups were American Board of Forensic Odontology, American Red Cross, Disaster Mortuary Operational Response Teams, Emergency System for Advance Registration of Volunteer Health Professionals, and Medical Reserve Corps. 


\section{Discussion}

We agree with the report of the American Dental Association (ADA) and American Dental Education Association (ADEA) terrorism and mass casualty curriculum workshop, which concluded that "dental schools should train all students in a core set of competencies related to bioterrorism and provide additional opportunities for further education." 17 That workshop outlined dentists' roles in responding to bioterrorism and other MFI events, placing responsibility on dental schools to prepare dental students. Disaster response and preparedness and bioterrorism training should also be extended to dental hygiene programs as an interdisciplinary opportunity to strengthen preparedness overall in the dental profession. ${ }^{17}$ MFIs are managed by inter- disciplinary teams, and interdisciplinary education provides an opportunity to integrate concepts and ideas from other disciplines, share resources, and coordinate preparedness and response objectives. ${ }^{5}$

Our study found that responding dental hygiene program directors felt dental hygienists play a vital role in disaster preparedness and response for MFIs, yet a large majority reported no formal instruction in disaster training in their curricula. The program directors who reported including disaster training were the same educators who indicated participating in past MFIs, specifically Hurricane Katrina, 9/11, and transportation accidents. Dental hygiene educators with MFI teaching experience should conduct research and publish their findings in peer-reviewed journals since accounts of dental hygienists participating in MFIs are outdated. We believe that most dental hygienists have a strong sense of community

Table 5. Cross tabulation of potential curriculum topics with perception that role of dental hygienists in mass fatality incidents (MFIs) should be in dental hygiene curricula

\begin{tabular}{|c|c|c|c|c|c|c|}
\hline \multirow[b]{2}{*}{ Curriculum Topic } & \multirow[b]{2}{*}{ Responses } & \multicolumn{3}{|c|}{$\begin{array}{l}\text { Role of Dental Hygienists in MFIs } \\
\text { Should Be in Dental Hygiene Curricula }\end{array}$} & \multicolumn{2}{|c|}{ Tests of Association } \\
\hline & & $\begin{array}{l}\text { Agree/ } \\
\text { Strongly } \\
\text { Agree }\end{array}$ & $\begin{array}{l}\text { Disagree/ } \\
\text { Strongly } \\
\text { Disagree }\end{array}$ & Total & $\begin{array}{l}\text { Test } \\
\text { Statistic } \\
\text { Value }\end{array}$ & p-value \\
\hline Personal protective equipment & $\begin{array}{l}\text { Imp./Very Imp. } \\
\text { Slightly Imp./Not Imp. }\end{array}$ & $\begin{array}{c}52 \\
3\end{array}$ & $\begin{array}{l}9 \\
7\end{array}$ & $\begin{array}{l}61 \\
10\end{array}$ & 0.001 & $<0.001$ \\
\hline Infection control & $\begin{array}{l}\text { Imp./Very Imp. } \\
\text { Slightly Imp./Not Imp. }\end{array}$ & $\begin{array}{l}48 \\
7\end{array}$ & $\begin{array}{l}8 \\
8\end{array}$ & $\begin{array}{l}56 \\
15\end{array}$ & 0.003 & 0.003 \\
\hline $\begin{array}{l}\text { Taking photographs of victim re- } \\
\text { mains }\end{array}$ & $\begin{array}{l}\text { Imp./Very Imp. } \\
\text { Slightly Imp./Not Imp. }\end{array}$ & $\begin{array}{l}43 \\
11\end{array}$ & $\begin{array}{l}7 \\
9\end{array}$ & $\begin{array}{l}50 \\
20\end{array}$ & 0.007 & 0.010 \\
\hline $\begin{array}{l}\text { Technique and radiation safety when } \\
\text { exposing dental radiographs on } \\
\text { victim remains }\end{array}$ & $\begin{array}{l}\text { Imp./Very Imp. } \\
\text { Slightly Imp./Not Imp. }\end{array}$ & $\begin{array}{c}51 \\
3\end{array}$ & $\begin{array}{l}9 \\
7\end{array}$ & $\begin{array}{l}60 \\
10\end{array}$ & 0.001 & $<0.001$ \\
\hline $\begin{array}{l}\text { Assisting with resecting a mandible } \\
\text { after the onset of rigor mortis }\end{array}$ & $\begin{array}{l}\text { Imp./Very Imp. } \\
\text { Slightly Imp./Not Imp. }\end{array}$ & $\begin{array}{l}38 \\
16\end{array}$ & $\begin{array}{c}4 \\
12\end{array}$ & $\begin{array}{l}42 \\
28\end{array}$ & 0.001 & 0.003 \\
\hline $\begin{array}{l}\text { Recording postmortem finding made } \\
\text { by an odontologist in victim identi- } \\
\text { fication software systems or official } \\
\text { forms }\end{array}$ & $\begin{array}{l}\text { Imp./Very Imp. } \\
\text { Slightly Imp./Not Imp. }\end{array}$ & $\begin{array}{c}50 \\
5\end{array}$ & $\begin{array}{l}9 \\
7\end{array}$ & $\begin{array}{l}59 \\
12\end{array}$ & 0.003 & 0.004 \\
\hline $\begin{array}{l}\text { Digitizing information collected from } \\
\text { dental records into identification } \\
\text { software }\end{array}$ & $\begin{array}{l}\text { Imp./Very Imp. } \\
\text { Slightly Imp./Not Imp. }\end{array}$ & $\begin{array}{c}49 \\
6\end{array}$ & $\begin{array}{l}9 \\
7\end{array}$ & $\begin{array}{l}58 \\
13\end{array}$ & 0.006 & 0.007 \\
\hline $\begin{array}{l}\text { Working collaboratively with mem- } \\
\text { bers of other professions volunteer- } \\
\text { ing for mass fatality incident }\end{array}$ & $\begin{array}{l}\text { Imp./Very Imp. } \\
\text { Slightly Imp./Not Imp. }\end{array}$ & $\begin{array}{c}52 \\
2\end{array}$ & $\begin{array}{l}7 \\
9\end{array}$ & $\begin{array}{l}59 \\
11\end{array}$ & 0.001 & $<0.001$ \\
\hline $\begin{array}{l}\text { Providing family assistance during } \\
\text { mass fatality incident }\end{array}$ & $\begin{array}{l}\text { Imp./Very Imp. } \\
\text { Slightly Imp./Not Imp. }\end{array}$ & $\begin{array}{c}47 \\
8\end{array}$ & $\begin{array}{c}5 \\
11\end{array}$ & $\begin{array}{l}52 \\
19\end{array}$ & 0.001 & $<0.001$ \\
\hline
\end{tabular}
(Probability) and its corresponding p-value. 
service and are willing to volunteer and that dental hygiene programs would be well advised to prepare and recruit future generations of students who want to be involved in MFI response. Nursing educators have also advocated disaster preparedness efforts in nursing curricula. ${ }^{7,8}$ Additionally, the dental hygiene educators in our study reported residing in areas perceived as high probability for disaster occurrence. This finding supports global statistics that show the U.S. experiences natural disasters annually, ${ }^{1,2,5}$ which alone suggests a need for greater MFI-related training.

Very few dental hygiene programs in our study included MFI preparedness content; however, most of the program directors indicated curriculum development was needed. Over half reported feeling the role of dental hygienists for MFIs should be part of the dental hygiene curriculum. The small percentage of programs with MFI content in our study suggests that dental hygiene students may be unfamiliar with MFI preparedness and response. If faculty members are not well prepared or lack real world experience in MFIs, it can be assumed that their students will not be prepared. A study of nursing schools also found a high percentage of faculty members inadequately prepared in disaster response planning, yet $53 \%$ of the participating schools reported offering disaster preparedness content. ${ }^{8}$ While dental hygiene program directors may feel a lack of expertise limits curriculum development, previous studies have found that nursing educators are finding strategies to educate themselves and overcome barriers. ${ }^{7,8}$

In our study, inconsistencies in course placement and method of delivery varied from lectures to webinars and case studies. The lack of standardization of core competencies for disaster preparedness education is also well documented in nursing and dentistry., ${ }^{4,514,18}$ Of the programs in our study that reported having MFI courses, the respondents noted having content in theory, radiology, anatomy, and medical emergency courses. Future studies need to gain more information on the number of dental schools and dental hygiene programs that offer multidisciplinary coursework in disaster preparedness. Dental and dental hygiene educators should work collaboratively when incorporating changes into curricula that benefit both fields.

Limitations of this study include a low response rate and the self-reporting of data. The $36 \%$ response rate could be attributable to program directors' lack of familiarity with mass fatality terms, or they may have considered the subject matter to be of low interest or a low priority in the context of the many needs to be addressed in their curricula. It is worth noting that our response rate of $36 \%$ is consistent with other surveys of dental hygiene program directors. A recent electronic survey by Minichbauer et al. on the inclusion of sleep medicine content in dental hygiene education had a response rate of $35 \%,{ }^{19}$ while other recent online surveys of dental hygiene programs had response rates of $48 \%$ and $46 \% .^{20,21}$ Another limitation may have resulted from the fact that the term "mass fatality" was not defined on the survey, so the respondents may have underreported the number of disasters with MFIs that occurred in their state. Responses were received from across the United States and the majority were from programs offering associate degrees and were not affiliated with dental schools, making them broadly consistent with U.S. dental hygiene education as a whole; nevertheless, our findings cannot be generalized to all U.S. dental hygiene programs.

Training and education of all dental professionals is needed if they are to contribute to the nation's response capabilities by integrating them into disaster preparedness and response during MFIs. ${ }^{12,15,22,23} \mathrm{Com}-$ munity and institutional disaster preparedness planning and training are essential for an effective broadbased response, ${ }^{16}$ and regular disaster preparedness training improves health care providers' confidence in responding to mass casualties. ${ }^{7}$ To optimize their efficiency and effectiveness, practitioners should work to gain the necessary skills and experience in forensic dental identification, while participating in regular preparedness exercises.

Dental hygiene programs offering MFI coursework should include content in science and theory courses. We recommend that programs not currently offering MFI training begin to explore ways to incorporate content into their curricula. Recommendations from the ADA-ADEA workshop suggested basic training in the areas of microbiology, pharmacology, and general pathology with optional advanced course work for further study. ${ }^{17}$ Incorporation of preparedness training into dental hygiene curricula would support that workshop's recommendations. Doing so should address the time requirement concern that the program directors in our study reported feeling was the most significant barrier to adding MFI content. We recommend adding the following topics to existing courses: knowledge and recognition of associated risks and hazards; postmortem dental coding and victim identification software systems (WinID, Plass Data DVI, UVIS/UDEM system, FBI/CJIS NCIC 
system, and web-based NamUS system); working on multi-verification teams; and safety and radiation techniques when working with portable radiation equipment and victim remains. Oral anatomy, theory, radiology, and community-based lectures would be ideal courses in which to incorporate core competencies for MFI training in these areas.

\section{Conclusion}

Our study was designed to assist those involved in mass fatality disaster preparedness and response and to provide a baseline for determining dental hygiene curriculum coverage of the subject. Although forensic odontologists and dental hygienists have contributed to identification of victims in MFIs, there are a limited number of trained dental professionals to assist in disaster victim identification. Most dental hygiene students have not received mass fatality preparedness and response training on infection control in a mortuary setting or radiation safety and technique when imaging dental remains. The results of this study can inform the dental hygiene profession, sponsors of continuing education programs, forensic academies and associations, and organizational leaders of disaster preparedness and response recruitment. Dental hygienists can assist in preparedness and response efforts in a way that leverages multidisciplinary teams when training programs are implemented. Our study emphasizes the need for more rigorous educational research in this specialty area.

\section{REFERENCES}

1. Guha-Sapir D, Hoyois P, Below R. Annual disaster statistical review, 2014: the numbers and trends. At: cred.be/download/download.php?file=sites/default/files/ ADSR_2014.pdf. Accessed 24 Sept. 2015.

2. Stoeckel DC, Merkley PJ, McGivney J. Forensic dental training in the dental school curriculum. J Forensic Sci 2007;52(3):684-6.

3. Jose MM, Dufrene C. Educational competencies and technologies for disaster preparedness in undergraduate nursing education: an integrative review. Nurse Educ Today 2014;34:543-51.

4. Swiss Re Sigma. Natural catastrophes and man-made disasters in 2014: convective and winter storms generate most losses. 2014. At: media.swissre.com/documents/ sigma2 2015 en final.pdf. Accessed 24 Sept. 2015.
5. Coleman L. Frequency of man-made disasters in the 20th century. J Contin Crisis Manage 2006;14:3-11.

6. Brannon LM, Connick CM. The role of the dental hygienist in mass disasters. J Forensic Sci 2000;45(2):381-3.

7. Baack S, Alfred D. Nurses' preparedness and perceived competence in managing disasters. J Nurs Scholarship 2013;45(3):281-7.

8. Schmidt CK, Davis JM, Sanders JL, et al. Exploring nursing students' level of preparedness for disaster response. Nurs Educ Perspect 2011;32(6):380-3.

9. U.S. Department of Homeland Security. Target capabilities list. 2007. At: www.fema.gov/pdf/government/training/ tcl.pdf. Accessed 24 Sept. 2015.

10. Ferguson DA, Sweet DJ, Craig BJ. Forensic dentistry and dental hygiene: how can the dental hygienist contribute? Can J Dent Hyg 2008;42(4):203-11.

11. Rawson R, Nelson B, Koot A. Mass disaster and the dental hygienist: the MGM fire. Dent Hyg 1983;57(12):12-8.

12. Newcomb T, Bruhn A, Giles B. The role of the dental hygienist in mass fatality incidents: are we prepared? J Dent Hyg 2015;89(3):143-51.

13. Zohn H, Dashkow S, Aschheim K, et al. The odontology victim identification skill assessment system. J Forensic Sci 2010;55(3):788-91.

14. More FG, Phelan J, Boylan R, et al. Predoctoral dental school curriculum for catastrophe preparedness. J Dent Educ 2004;68(8):851-8.

15. Bruhn A, Newcomb T, Giles B. Evaluating imaging techniques for intraoral forensic radiography with the dental hygienist as part of the forensic radiology team. J Forensic Ident 2016;66(1):22-36.

16. Abraham RT, Walls RT, Fischer M, et al. Tabletop scenarios for realism in bioterrorism and threat preparedness. West Virginia Med J 2012;108(6):12-7.

17. Chmar JE, Ranney RR, Guay AH, et al. Incorporating bioterrorism training into dental education: report of ADA-ADEA terrorism and mass casualty curriculum development workshop. J Dent Educ 2004;68(11):1196-9.

18. Glotzer DL, More FG, Phelan J, et al. Introducing a senior course on catastrophe preparedness into the dental school curriculum. J Dent Educ 2006;70(3):225-30.

19. Minichbauer BC, Sheats RD, Wilder RS, et al. Sleep medicine in dental hygiene education. J Dent Educ 2015;79(5):484-92.

20. Navickis MA, Bray KK, Overman PR, et al. Examining clinical assessment practices in U.S. dental hygiene programs. J Dent Educ 2010;74(3):297-310.

21. DeBate RD, Shuman D, Tedesco LA. Eating disorders in the oral health curriculum. J Dent Educ 2007;71(5): 655-63.

22. Nuzzolese E, Lepore M, Cukovi-Bagic I, et al. Forensic sciences and forensic odontology: issue for dental hygienist and therapists. Int Dent J 2008;58(6):342-8.

23. Newcomb T, Bruhn A, Ulmer L, Diawara N. Performance of dental hygiene students in mass fatality training and radiographic imaging of dental remains. J Dent Hyg 2015;89(5):313-20. 